\title{
Comparison of gene expression in fresh and frozen-thawed human preimplantation embryos
}

\author{
Lisa Shaw ${ }^{1}$, Sharon F Sneddon ${ }^{1,2}$, Daniel R Brison ${ }^{1,2}$ and Susan J Kimber ${ }^{3}$ \\ ${ }^{1}$ Faculty of Medical and Human Sciences, University of Manchester, Manchester M13 9PT, UK, ${ }^{2}$ Manchester \\ Academic Health Sciences Centre, St Mary's Hospital, Central Manchester University Hospitals NHS Foundation \\ Trust, Manchester M13 9WL, UK and ${ }^{3}$ Faculty of Life Sciences, University of Manchester, Michael Smith Building, \\ Oxford Road, Manchester M13 9PT, UK
}

Correspondence should be addressed to S J Kimber; Email: sue.kimber@manchester.ac.uk

L Shaw and S F Sneddon contributed equally to this work

L Shaw is now at School of Pharmacy and Biomedical Sciences, University of Central Lancashire, Preston, PR1 2HE, UK

\begin{abstract}
Identification and characterisation of differentially regulated genes in preimplantation human embryonic development are required to improve embryo quality and pregnancy rates in IVF. In this study, we examined expression of a number of genes known to be critical for early development and compared expression profiles in individual preimplantation human embryos to establish any differences in gene expression in fresh compared to frozen-thawed embryos used routinely in IVF. We analysed expression of 19 genes by cDNA amplification followed by quantitative real-time PCR in a panel of $\mathbf{4 4}$ fresh and frozen-thawed human preimplantation embryos. Fresh embryos were obtained from surplus early cleavage stage embryos and frozen-thawed embryos from cryopreserved $2 \mathrm{PN}$ embryos. Our aim was to determine differences in gene expression between fresh and frozen-thawed human embryos, but we also identified differences in developmental expression patterns for particular genes. We show that overall gene expression among embryos of the same stage is highly variable and our results indicate that expression levels between groups did differ and differences in expression of individual genes was detected. Our results show that gene expression from frozen-thawed embryos is more consistent when compared with fresh, suggesting that cryopreserved embryos may represent a reliable source for studying the molecular events underpinning early human embryo development.

Reproduction (2012) 144 569-582
\end{abstract}

\section{Introduction}

The identification and characterisation of developmentally regulated genes in oocytes and early embryos are important to inform our understanding of the sequence of events leading to successful implantation and generation of the human foetus as well as the development of criteria to assess the competency of early embryos in assisted conception (Watson et al. 1999, Cui \& Kim 2007).

The correct regulation of gene expression during preimplantation development is critical for normal development of the mammalian embryo (Hamatani et al. 2006, Kimber et al. 2008). Successful embryonic development requires a series of co-ordinated molecular and cellular events culminating in a blastocyst. Embryonic genome activation (EGA) was first thought to occur at the four- to eight-cell stage in the human (Braude et al. 1988) but Vassena et al. (2011) have shown that it can occur as early as the two-cell stage in the human and coincides with the rapid de-adenylation and subsequent degradation of the maternal transcripts (Telford et al. 1990, Vassena et al. 2011). Following this, compaction of the morula occurs establishing the first true cell-to-cell adhesion within the embryo (Kimber 1990). Blastocyst formation takes place from day 5 and involves the first differentiation event in the embryo resulting in the generation of two distinct cell types: the trophectoderm (TE) and the inner cell mass (ICM) (Kimber 1990, Ralston \& Rossant 2005). A range of transcription factors within these two cell types then trigger differentiation and activation of downstream molecular pathways.

The efficacy of classical IVF techniques is still impaired by poor implantation and pregnancy rates after embryo transfer (Gasca et al. 2007). This is mainly due to a lack of reliable criteria for the selection of embryos with sufficient development potential. Several studies have provided evidence that levels of expression 
of some genes could be used as markers of embryo competence and capacity to sustain a successful pregnancy (Patrizio et al. 2007, Hamel et al. 2008). Indeed, defects in single genes are sufficient to cause implantation failure (Copp 1995), suggesting that identification of single gene changes could be useful for embryo selection in IVF. However, due to difficulties in obtaining material, there are few comprehensive studies on gene expression.

The use of surplus cryopreserved human embryos in gene expression studies provides a source of embryos available for research. The application of embryo cryopreservation is a routine feature of nearly all clinical IVF programmes since its inception in the 1980's (Trounson \& Mohr 1983). Most IVF centres have careful guidelines meaning only good-quality embryos are selected for freezing, to give the best chance of implantation following thawing. In cases where patients no longer require the embryos for treatment and they would be discarded, these embryos are often donated to research.

Although embryo freezing has been shown to have little effect on cell surface antigen expression and distribution in murine embryos (Wood et al. 1992), it is unclear whether it affects developmental gene expression. This may in turn be detrimental to embryo quality, blastocyst formation and/or implantation. Indeed, potential problems with aberrant gene expression in frozen-thawed embryos have been reported in human embryos (Tachataki et al. 2003). On the other hand, recent clinical data show that babies born following embryo freezing are healthy and have higher birthweights than from fresh embryos (Wennerholm et al. 2009, Vergouw et al. 2012). Therefore, in this study, we set out to compare the expression profile of a number of key genes from the pronucleate (2PN) stage to the blastocyst in fresh and frozen-thawed individual preimplantation human embryos. The panel of genes chosen includes oocyte-specific markers, markers of pluripotency and differentiation, pro- and anti-apoptotic genes and stress markers. These were assessed by cDNA amplification followed by quantitative real-time quantitative PCR (qPCR). This analysis is of critical importance to human IVF, as freezing is offered by most clinics, as well as informing our understanding of human preimplantation development.

\section{Results \\ Embryo culture}

A total of 25 embryos frozen at the 2PN stage and 19 fresh embryos were used in the study. The frozen cohort obtained from cryopreserved 2PN embryos that were subsequently thawed were either lysed after a short recovery period or further cultured to the four-cell, eight-cell and blastocyst stages. The fresh embryos used in this study were selected for analysis on the basis of their morphological grade, which was matched to the grade of the corresponding frozen-thawed embryos as per Steer et al. (1992). Embryos were assessed every $12 \mathrm{~h}$ and only those graded 3 or 4 for blastomere size, blastomere evenness and percentage of fragmentation were used in the study.

\section{Developmental gene expression in embryos obtained from frozen-thawed zygotes and fresh human embryos}

Our aim was to determine overall differences in gene expression between fresh and frozen embryos by probing for expression of a panel of 19 genes. Given the nature of our amplification method (global amplification followed by gene-specific PCR), we do not class a gene to be expressed unless it is detected before 37 cycles with qPCR. Although lower level signal for some genes could be detected in certain samples, we have not recorded this as 'true expression' if the level fell outside of our inclusion criteria. $\beta$-ACTIN was expressed in all embryos, as this was the minimum inclusion criterion for the study; however, it showed variation in expression level when normalised to total polyA cDNA.

Figures 1, 2, 3 and 4 show the individual expression levels in fresh and frozen embryos for each gene. We first assessed genes associated with cell survival (BCL2L1 $(B C L X), B C L 2, B A X$ and TP53 (P53); Fig. 1), stress response, the formation of TE and the maintenance of the pluripotent stem cell compartment of the embryo (GAS5 and POU5F1 (also known as OCT3B/4), SOX2, NANOG, ZFP42 (REX1), CDX2 and EOMES; Figs 2 and 3), and finally genes involved in genome activation, transcription, translation initiation, germ cell and oocyte function (DAZL, EIF1AX, FIGLA, NLRP5 (MATER), ZAR1 (ZAR), ZSCAN1 and TSC2; Figs 3 and 4).

Figure 5 shows the mean expression levels for individual genes in frozen and fresh embryos during preimplantation development. Of the 19 genes investigated in this study, BAX, GAS5, SOX2, NANOG, CDX2, EIF1AX, NLRP5, ZAR1, ZSCAN4 and TSC2 showed significant differences in mean levels of expression either during preimplantation development or between stagematched frozen and fresh embryos. These significant differences are summarised in Fig. 6.

$B A X$ expression was significantly upregulated between the four-cell and blastocyst stages of development $(P<0.01)$ in the frozen embryo panel, and there was also a significant difference in mean expression when comparing frozen and fresh blastocysts $(P<0.05)$. GAS5 was also significantly upregulated in the frozen embryo panel from the 2PN stage to the eight-cell and blastocyst stages $(P<0.05)$, but the mean levels of GAS5 expression were comparable between frozen and fresh embryos at all stages of development.

SOX2 was upregulated in frozen embryos between the 2PN and eight-cell and 2PN and blastocyst stages 

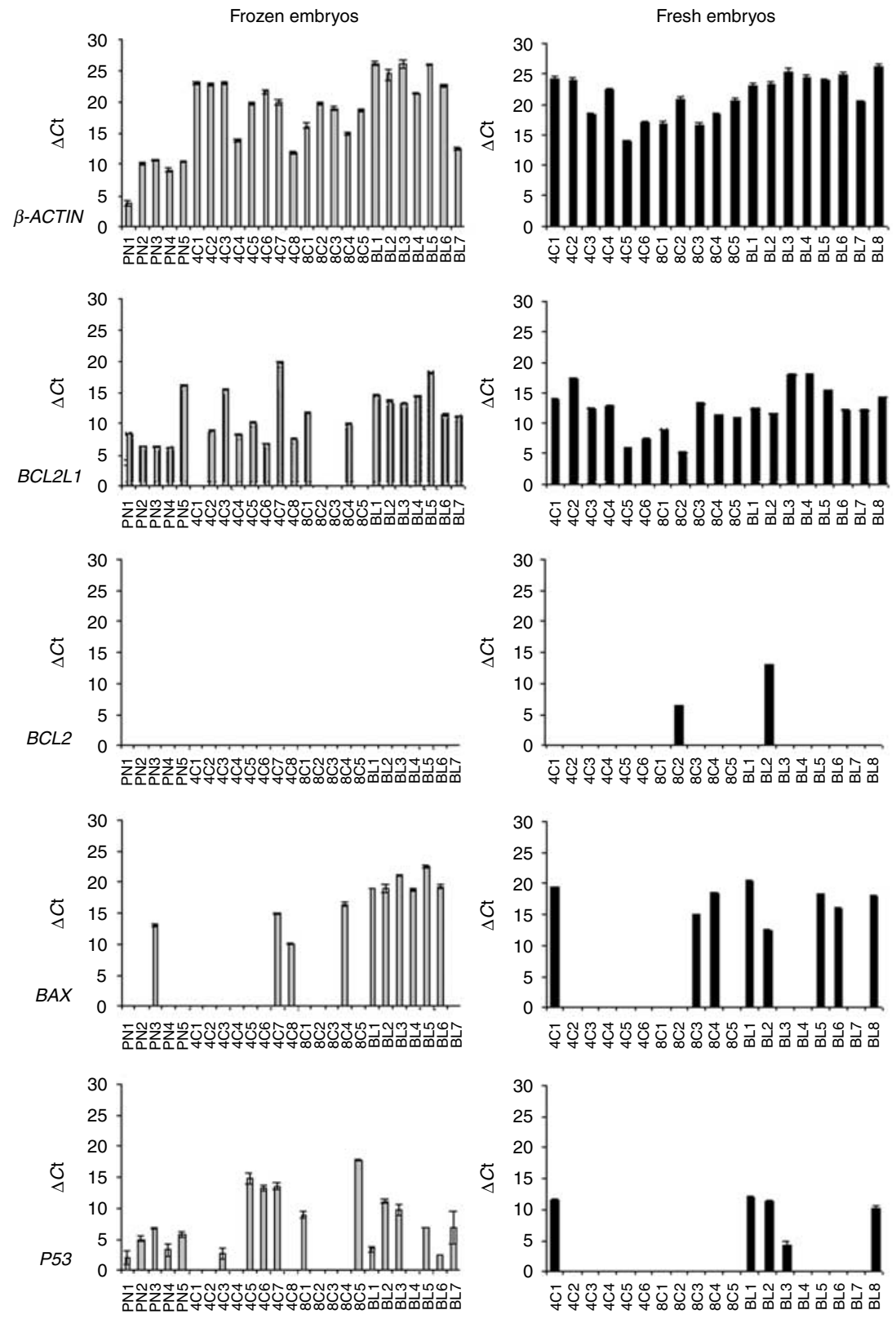

Figure 1 Individual expression levels of $\beta$-ACTIN, which was used as a minimum inclusion criterion, and the apoptosis-related genes BCL2L1, BCL2, $B A X$ and TP53 in frozen (grey bars) and fresh (black bars) embryos.
$(P<0.01)$, and there was also a significant difference in the mean expression between frozen and fresh blastocysts $(P<0.05)$. A significant difference was observed in NANOG expression during development between 2PN and eight-cell, 2PN and blastocyst and four-cell and blastocyst in the frozen embryo panel, as well as between both the four- and eight-cell stages and blastocyst in the fresh cohort of embryos $(P<0.01)$. When comparing the frozen and fresh embryos at the eight-cell stage, there was a significant difference in NANOG expression $(P<0.01)$. In the frozen-thawed panel, $C D X 2$ was significantly upregulated from the $2 \mathrm{PN}$ stage to the blastocyst stage $(P<0.01)$. Expression of $C D X 2$ was significantly higher in the fresh cohort at the four- and eight-cell stage compared with frozen-thawed embryos $(P<0.01)$. EIF1AX expression was significantly upregulated from the $2 \mathrm{PN}$ to the eight-cell and blastocyst stages of development in the frozen panel $(P<0.05)$, and there was a significant difference in expression at the eight-cell stage between frozen and fresh embryos $(P<0.05)$.

$N L R P 5$ expression was significantly increased in the frozen panel between $2 \mathrm{PN}$ and the four-cell stage $(P<0.05)$, coinciding with the onset of EGA. This level of expression was comparable to the eight-cell stage but then significantly declined at the blastocyst stage $(P<0.05)$. There was a significant difference in mean expression of $Z A R 1$ between frozen and fresh embryos at 

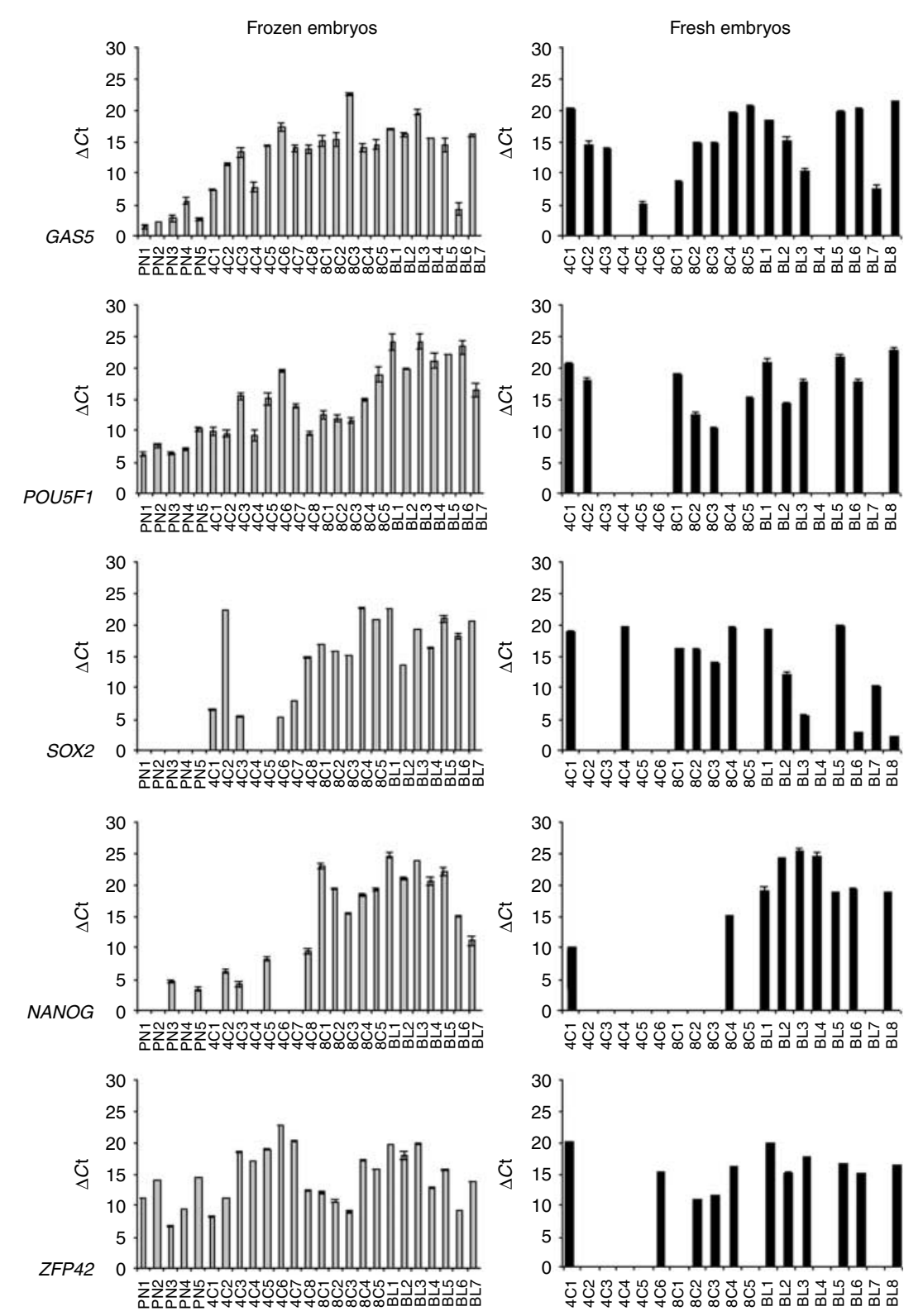

Figure 2 Individual expression levels of the stress response gene GAS5 and the pluripotencyrelated genes POU5F1, SOX2, NANOG and ZFP42 in frozen (grey bars) and fresh (black bars) embryos. the four-cell stage $(P<0.05)$. ZSCAN4 was developmentally regulated in both frozen and fresh embryos. There was significant upregulation of ZSCAN4 between the fresh four-cell and eight-cell embryos $(P<0.05)$ and mean expression levels peaked at the eight-cell stage in both the frozen and the fresh embryo panel. Expression levels declined between the eight-cell and blastocyst stages, but this finding was significant only in the frozen embryo panel $(P<0.05)$. The mean expression level of TSC2 was significantly increased in the frozen embryo panel in which the highest expression was detected at the blastocyst stage. Expression of TSC2 was comparable at all stages of development in the fresh embryo panel but a significant increase was observed in the number of frozen blastocysts expressing TSC2 when compared with the four-cell stage. A significant difference was observed in TSC2 expression between the frozen and fresh blastocysts $(P<0.05$; Fig. 5$)$.

As Fig. 5 depicts the mean expression levels of genes in stage-matched frozen and fresh embryos, the significant differences obtained by analysing data in this way could be attributed to a number of embryos expressing low levels of a particular gene, or to one embryo expressing an exceptionally high level of a particular gene. Thus, embryo competence may not be inferred from particularly high or low levels of gene expression, but rather whether the embryo expresses the gene in the first instance. We therefore addressed this by examining the number of individual frozen and fresh embryos, which expressed a given gene at the four-cell, 

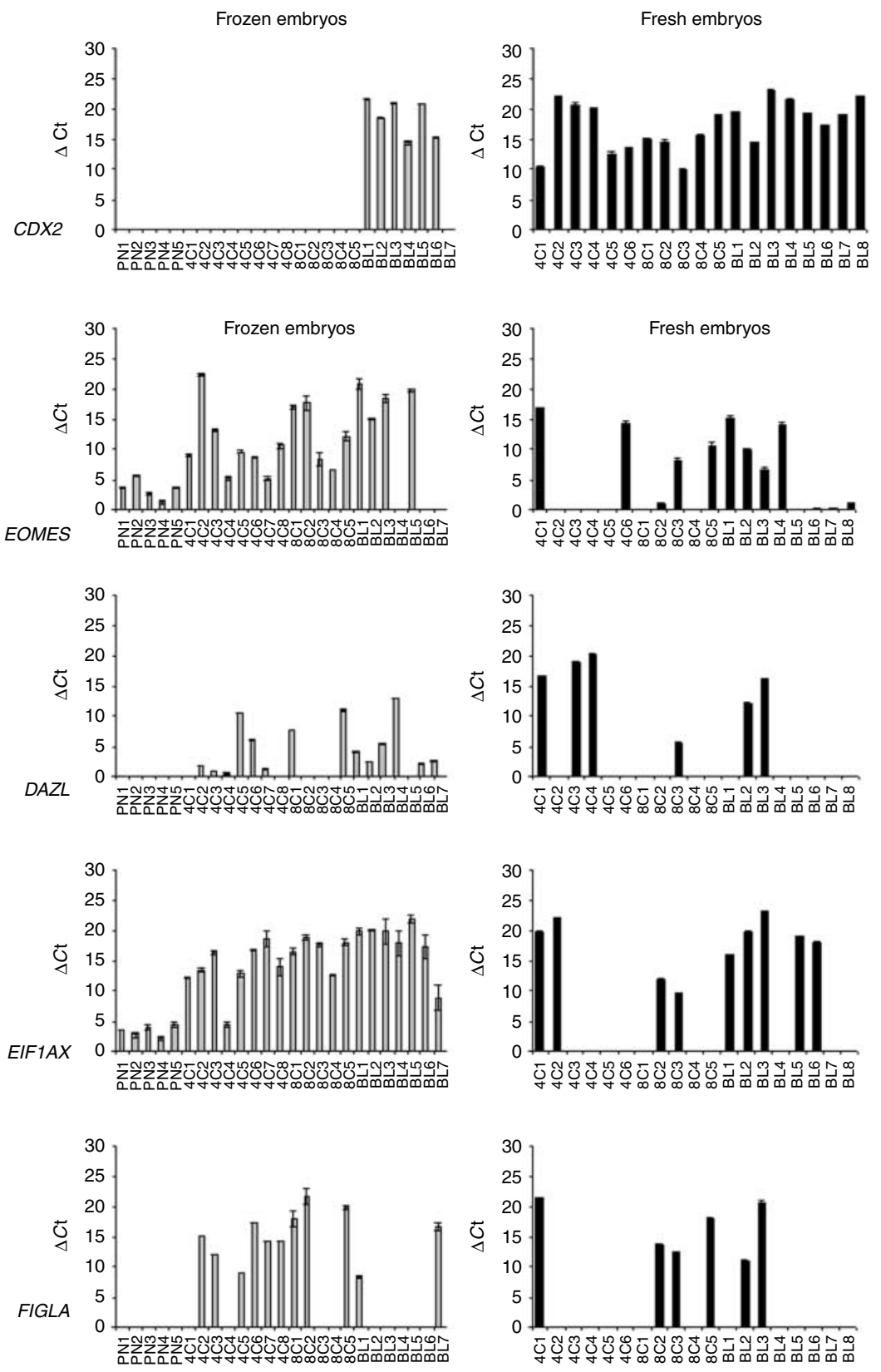

Figure 3 Individual expression levels of genes associated with trophectoderm specification $C D X 2$ and EOMES, the maternal effect gene $D A Z L$ and genes associated with embryonic genome activation, EIF41AX and FIGLA in frozen (grey bars) and fresh (black bars) embryos. eight-cell and blastocyst stages of development (Table 2). Significant differences were observed in the number of embryos expressing POU5F1, ZFP42, CDX2 and EOMES between the fresh and frozen-thawed panel when they reached the four-cell stage $(P<0.05, P<0.05, P<0.001$ and $P<0.05$ respectively). At the eight-cell stage, there was no significant difference in the number of embryos expressing any gene between fresh and frozen embryos apart from $C D X 2$, which is absent from the frozen panel, yet expressed in all the fresh eight-cell embryos $(P<0.01)$. There was a significant difference in the number of blastocysts expressing NLRP5 in the frozen panel relative to the number of blastocysts in the fresh panel $(P<0.05)$. Overall, the frozen embryos expressed a higher number of genes per embryo than fresh (Table 3), but this finding was not significant.

\section{Discussion}

The increasing application of IVF emphasises the need to better characterise the molecular events that occur during normal embryonic development. The gene expression patterns of human IVF embryos can vary quite significantly, and these patterns may provide insights into embryo quality and the potential to produce a healthy live birth after IVF, information of increasing importance to a more effective single embryo transfer (SET) policy. Although there are limitations in 


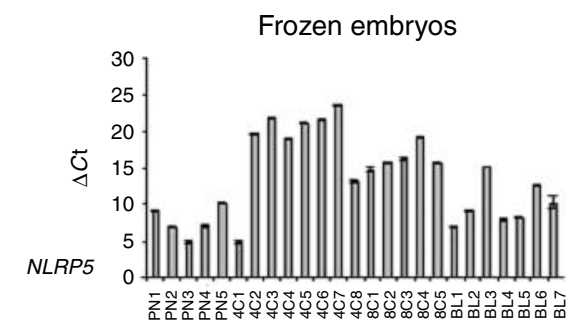

Frozen embryos
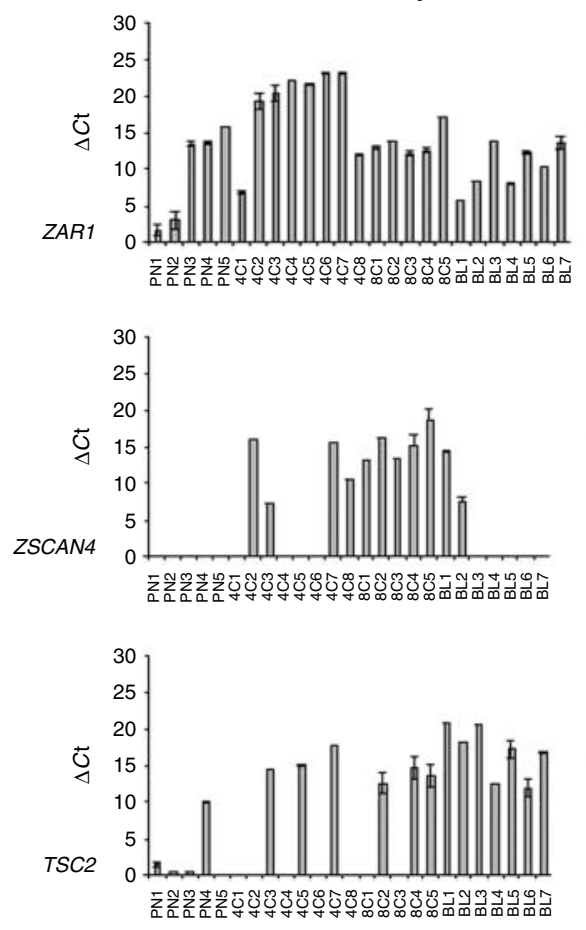

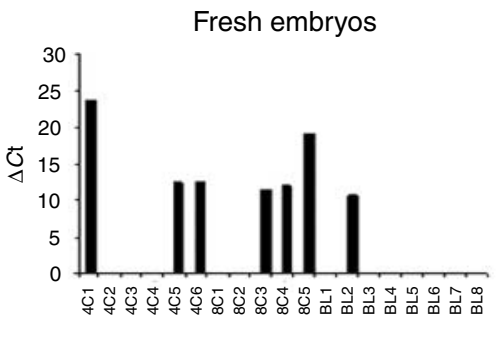

Fresh embryos
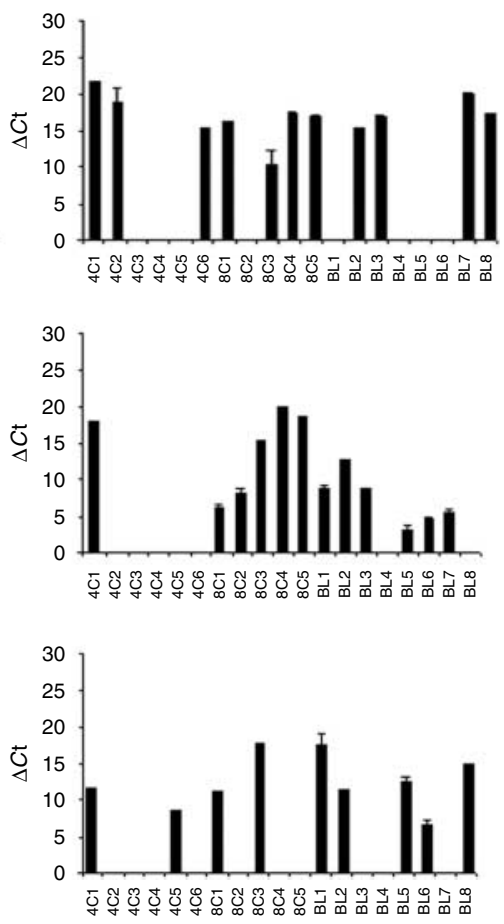

Figure 4 Individual expression levels of the maternal effect genes NLRP5, ZAR1, ZCAN4 and TSC2 in frozen (grey bars) and fresh (black bars) embryos. studying transcript levels, as regulation may occur posttranscriptionally or post-translationally, where there is a need to study small numbers of precious cells or embryos, transcript analysis can provide invaluable information not available by other techniques. Embryo freezing allows patients more attempts at achieving a pregnancy from a single cycle avoiding further cycles of hormonal stimulation as well as facilitating increased application of SET to avoid multiple pregnancies (Roberts et al. 2010). Various studies have shown the efficacy of frozen embryos in producing offspring that are healthy (Aytoz et al. 1999, Belva et al. 2008) and of higher birthweight (Wennerholm et al. 2009, Vergouw et al. 2012), but some reports have suggested that frozen embryos exhibit altered gene expression (Tachataki et al. 2003, Gardner \& Lane 2005). By allowing embryos to develop through the preimplantation period, we can identify whether cryopreservation perturbs the normal pattern of developmental gene expression or whether the quality of such embryos ensures a better developmental progression compared with equivalent fresh embryos. Our panel of frozen-thawed embryos provide a reliable source for studying human embryo development being morphologically matched to the fresh panel of embryos. It showed more consistent expression in target genes known for their importance in embryo development. This difference could be attributed to a consistent, directional response to the cryopreservation process, thereby generating embryos that are developmentally competent. Although the greater expression of $B A X$ in blastocysts from the frozen group could suggest activation of death pathways, there is no difference in TP53 and a corresponding increase in the number of embryos expressing eukaryotic elongation initiation factor 1A (EIF1AX, also known as EIF1A), a marker for EGA (Magnani et al. 2008). This may suggest that frozen embryos have greater developmental potential than fresh, although a larger scale study would be required to support this. In porcine embryos, it has been suggested that EIF1AX can be used to assess embryo quality (Magnani et al. 2008), and we have previously shown it to be expressed throughout preimplantation human development (Kimber et al. 2008). 

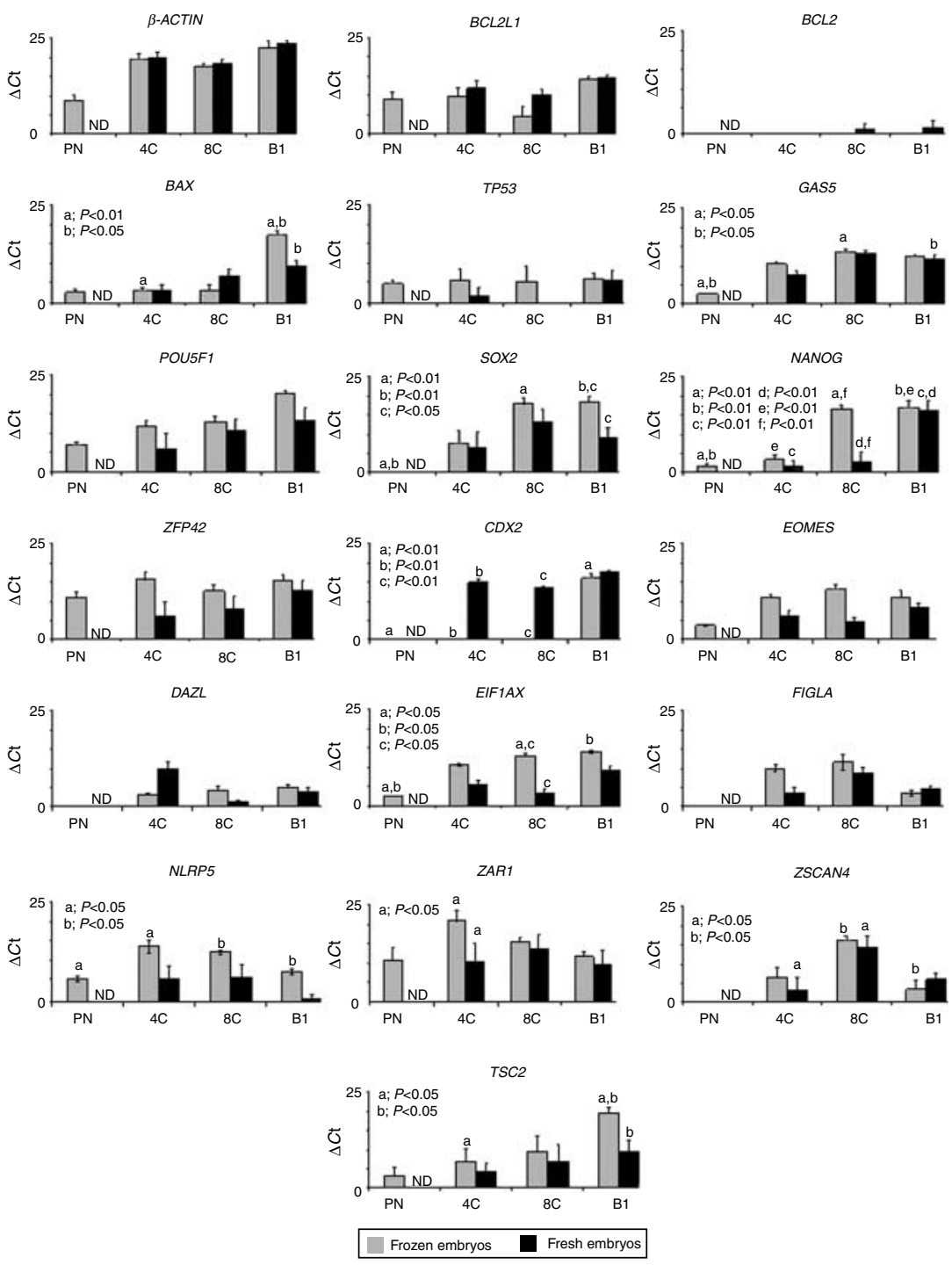

Figure 5 Mean gene expression for individual genes in frozen (grey bars) and fresh embryos (black bars) during preimplantation development. On each bar chart, pairs of letters indicate significant differences between groups ( $P$ values as indicated on the graph). Mean levels of gene expression of BAX, SOX2, CDX2, EIF1AX, NLRP5, GAS5 and TSC2 showed significant changes in the frozen embryo panel throughout preimplantation development whereas NANOG and ZSCAN4 showed significant changes in expression in both the frozen and fresh embryo panel during preimplantation development. Within each of the stages of preimplantation development, significant differences in mean expression levels of $B A X, S O X 2, N A N O G, C D X 2$, EIF1AX, ZAR1 and TSC2 were detected between frozen-thawed and fresh embryos.

\section{Apoptosis- and stress-related genes}

Apoptosis has been demonstrated in preimplantation embryos of many mammalian species including humans (Hardy 1999, Meier et al. 2000) and is an important response to culture stress, with a possible role in the removal of damaged embryonic cells (Brison \& Schultz 1997, Hardy 1999, Brison 2000). The balance between expression of pro-apoptotic (e.g. $B A X)$ and antiapoptotic (e.g. $B C L 2$ and $B C L 2 L 1$ ) genes may determine cell survival, including in human embryos (Metcalfe et al. 2004). We previously detected expression of the anti-apoptotic gene BCL2 in 45/46 four-cell or later human embryos (Metcalfe et al. 2004), but in only two of the fresh embryos and no frozen embryos examined here. Culture conditions can activate expression of $B C / 2$ family genes in mouse (Jurisicova et al. 1998) and human embryos (Wells et al. 2005), and it is possible that in the culture conditions used in our study, induction was largely absent. In contrast, BCL2L1, an independent regulator of apoptosis, was expressed in all but four (frozen) embryos and may act to oppose the pro-apoptotic effect of $B A X$, the most abundantly expressed pro-apoptotic member of the BCL2 family in mammalian oocytes and early cleavage stage embryos. $B A X$ expression in all but one frozen blastocyst and $5 / 8$ fresh blastocysts agrees with our previous work (Metcalfe et al. 2004) demonstrating almost universal expression in preimplantation human embryos, including higher expression in blastocysts after freezing, although others have suggested that its expression in blastocysts correlates with poor morphology (Guillemin et al. 2009). In future, the ratio and subcellular localisation of $B C L 2$ family member proteins should be examined, as this has been suggested as important for embryo competency (Perumalsamy et al. 2010, Boumela et al. 2011). TP53, a key inducer of cell cycle arrest and apoptosis, showed variable expression in both frozen and fresh embryos, suggesting that the freeze- 


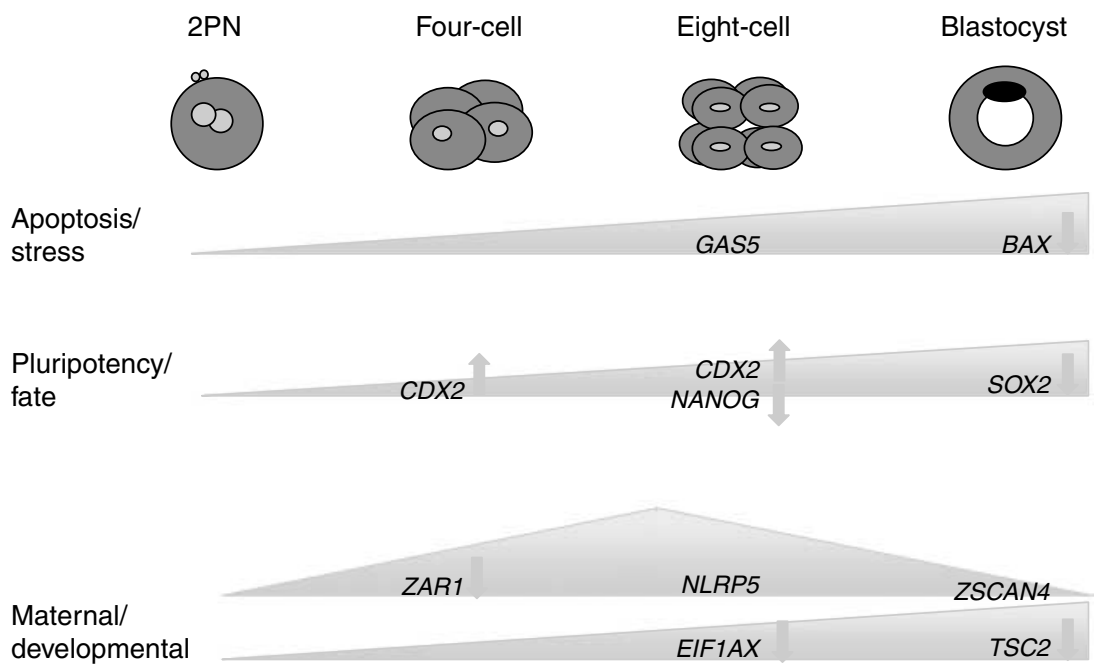

Figure 6 Expression of developmentally regulated genes (grey boxes) in embryos obtained from frozen-thawed zygotes. The expression pattern in each gene group is indicated by the entire box, with significant differences for mean levels of expression of each gene in fresh embryos indicated with a gene name and a black arrows at the appropriate stage. Downward arrows indicate reduced expression in fresh embryos; upward arrows for $C D X 2$ indicate increased expression of this gene in fresh embryos. For simplicity, only genes that show significant differences in mean expression levels during different stages of development and/or between the frozen and fresh embryo cohorts have been included. GAS5 and BAX were significantly upregulated during development of frozen-thawed embryos, with a similar pattern seen in fresh counterparts; however, there was a significant difference in mean expression of BAX between frozen and fresh blastocysts. NANOG and SOX2 showed significant differences in expression during development of the embryos after freezing and a significant difference in mean expression between frozen and fresh embryos at the eight-cell and blastocyst stages respectively. CDX2 was significantly upregulated during development of the frozen embryo cohort but consistently expressed at all stages of development in the fresh embryo panel; thus, significant differences were observed in mean levels of $C D X 2$ expression between the frozen and fresh embryos at the four-cell and eight-cell stages of development. ZAR1, NLRP5 and ZSCAN4 were developmentally regulated in the frozen embryo cohort and there was a significant difference in mean ZAR1 expression between fresh and frozen embryos at the four-cell stage. EIF1AX and TSC2 increased during the development of the frozen embryo cohort and significant differences in mean expression levels between the two embryo cohorts were observed at the eight-cell stage and blastocyst stage respectively.

thaw process is not responsible for inducing stress when compared to the fresh embryo group. This is also reflected in the similar expression of GAS5 in frozen and fresh embryos. Expression of Gas5 and associated growth arrest genes increases significantly when exponentially multiplying cells are exposed to a variety of stresses including inadequate nutrition or removal of serum. Our data show a significant increase in GAS5 with development of embryos following freezing, with a similar pattern in fresh embryos, but no difference between fresh and frozen (summarised in Fig. 6). GAS5 could be activated as part of the embryonic developmental programme or in response to culture stress, but apparently not as a result of cryopreservation stress. BAX increased during development in both groups. As only one difference was seen between fresh and frozen embryos (increased $B A X$ in frozen blastocysts; see Fig. 6), stress-related programmes appear to be either an inherent feature of embryonic development or related to culture stress, rather than cryopreservation.

\section{Pluripotency-related genes}

All frozen embryos expressed both POU5F1 and ZFP42, markers of pluripotency previously shown to be expressed throughout murine and human preimplantation development (Palmieri et al. 1994, Hansis et al. 2000, Pesce \& Scholer 2001). The majority of fresh embryos also expressed high levels of POU5F1 and ZFP42 (12/19 and 11/19 embryos respectively), but at the four-cell stage, the number of POU5F1- and ZFP42expressing embryos was significantly higher for frozen than for fresh embryos. There was an increase in the expression of two other pluripotency-regulating genes, SOX2 and NANOG, during embryo development after freezing, a pattern consistent with Vassena et al. (2011). A similar pattern was seen in fresh embryos, but with lower levels of expression at the eight-cell (SOX2 and $N A N O G$ ) and blastocyst (SOX2) stages (summarised in Fig. 6). The homeodomain transcription factor NANOG maintains the pluripotent early epiblast and prevents differentiation to primitive endoderm (Chambers et al. 2003), a critically important function in development. We previously demonstrated a variable expression pattern of the SRY-related HMG box transcription factor, SOX2 (Kimber et al. 2008, Sneddon et al. 2011), in human embryos, suggesting its role as a sensitive marker of developmental potential and embryo viability in the human. This study showed a more consistent pattern of expression in frozen embryos, particularly from the 
eight-cell stage. It has been shown in murine embryos that cells of the ICM do not develop synchronously (Fleming 1987), which could be one explanation for the observed heterogeneity of SOX2 expression in human embryos. In any case, the consistent expression of POU5F1, SOX2, NANOG and ZFP42 in the frozen blastocysts suggests the emergence of a healthy ICM population in these embryos. Transcription profiling by Guo et al. (2010) indicated little difference in the expression of 48 genes between individual murine blastomeres from six to ten embryos up to the eightcell stage: virtually, all eight-cell stage blastomeres were shown to express a number of lineage-specific genes including Nanog, Gata6 and Pou5f1.

\section{Genes associated with TE specification}

$C d x 2$ is essential for murine trophoblast development (Strumpf et al. 2005). The pattern of CDX2 expression in embryos after freezing was consistent with its role in trophoblast, with transcripts only seen at the blastocyst stage with the formation of TE as shown previously (Kimber et al. 2008). Surprisingly, CDX2 was consistently expressed at all stages by fresh embryos (summarised in Fig. 6), which could be a consequence of a lack of degradation of maternal CDX2, although any role of maternal CDX2 has still to be elucidated, or premature TE gene activation. Other work has shown early and variable expression of $C d x 2$ in blastomeres of murine eight-cell to morula stages and not all cleaving murine blastomeres that express $C d \times 2$ go on to form TE (Ralston \& Rossant 2008, Guo et al. 2010). In contrast, EOMES, a downstream target of CDX2 in TE (and important in early endoderm/mesoderm differentiation), was expressed in significantly more frozen embryos than fresh at the four-cell stage, but in some embryos at each stage in both populations, which is in agreement with the variable expression seen in Kimber et al. (2008). However, this is surprising in light of the absence of CDX2 in the early embryos of the frozen cohort.

\section{Maternal effect genes}

A low level of maternally expressed transcripts was identified by Zhang et al. (2009) in preimplantation embryos, who proposed early embryos to be 'self-sufficient' before implantation. However, this cannot account for the expression of the maternal gene TSC2 in more embryos in the frozen group from four-cell onward, as there is little expression in 2PNs. NLRP5 and $Z A R 1$, in contrast, are maternally expressed genes detected in all embryos at all stages of development following freezing, which, along with the expression of EIF1AX, may reflect the inability of the frozen embryos to cease maternal transcription in a timely fashion, although at least half of fresh cleavage stage (NLRP5 and ZAR1) and blastocysts (ZAR1) do express these genes. NLRP5 forms part of the subcortical mitotic complex and is required for passage through cleavage divisions in mouse development (Li et al. 2010) and may play a role in RNA processing and cell metabolism (Sena et al. 2009), which could account for the expression we see at later stages. DAZL has been suggested to be expressed throughout human embryo development from maternal transcripts (Cauffman et al. 2005); however, only a proportion of both our sets of embryos contained transcripts, perhaps consistent with the suggestion that $D A Z L$ transcripts are a marker of good-quality embryos (Cauffman et al. 2005).

Of the seven maternal effect/early genes studied, four (EIF1AX, NLRP5, ZSCAN4 and TSC2) showed significant developmental regulation in embryos following freezing. ZSCAN4 showed a similar increase in fresh embryos, but EIF1AX, ZAR1 and TSC2 showed significantly lower levels of mean expression in fresh compared with frozen embryos at various stages of development (summarised in Fig. 6).

Previous studies have reported that freezing protocols may affect gene expression in embryos of several species (Goto et al. 2002, Chandrakanthan et al. 2007), which in turn may result in poor-quality embryos. However, topgrade individual frozen-thawed human embryos have also been reported to have highly variable gene expression (Kimber et al. 2008). Embryos from our frozen-thawed panel showed relatively consistent gene expression throughout, and importantly, sibling embryos from our frozen embryo panel resulted in pregnancy. Although the fresh embryos were morphologically matched to those embryos thawed and cultured from the 2PN stage, fewer of the fresh embryos came from pregnant cycles, and we note that morphology is not necessarily linked to embryo developmental competence. Improved methods of identifying viable embryos for IVF are needed, and indeed the current use of morphology alone in most centres may contribute to the low success rate in assisted conception.

\section{Is gene expression different in frozen-thawed embryos?}

Our results show more consistent gene expression in embryos at various stages following freezing. It is unknown whether this is due to the selection pressure of the freeze-thaw process causing aberrant ability to regulate certain developmental genes, or whether the embryos that survived were of better quality from the outset thus exhibiting greater ability for transcription. However, the latter is consistent with the data showing better perinatal outcomes and higher birth weights in babies born from frozen embryos (Belva et al. 2008, Wennerholm et al. 2009, Vergouw et al. 2012). Assisted reproductive technologies still have lower than desired success rates and this investigation supports the premise that patients will benefit from continued close 
examination of embryo quality, allowing only replacement of the best embryos, coupled with embryo cryopreservation. We further propose that cryopreserved embryos are a reliable source for studying embryo development and will help in development of new methods of identifying the best embryos for transfer. This latter is particularly important with the move to SET programmes to ensure high pregnancy success rates.

\section{Materials and Methods}

\section{Embryos}

Human embryos were donated to research after patient consent, with approval of the Central Manchester Research Ethics Committee and the Human Fertilisation and Embryology Authority (research licence R0026). Basal characteristics of the patients donating embryos are as detailed in Roberts et al. (2010). Frozen 2PN stage embryos, displaying two clear pronuclei $(\mathrm{PN})$, which were surplus to IVF requirements and fresh embryos surplus to IVF requirement were obtained from Saint Mary's Hospital and Manchester Fertility Services Manchester. All fresh embryos were surplus to infertility treatment but were of equivalent morphological quality and developmental timing and carefully matched to the embryos obtained from frozen-thawed zygotes, according to standard clinical grading systems used at St Mary's Hospital (Steer et al. 1992). Blastocysts were graded using the Gardner and Schoolcraft method (Gardner \& Schoolcraft 1999). All the frozen embryos, three of the fresh four-cell embryos and two of the fresh blastocysts, came from treatment cycles in which sibling embryos had given rise to live births.

Two PN embryos were frozen using the Embryo Freezing Pack (Medicult UK Ltd., Surrey, UK), which is a propylene glycol- and sucrose-based system following the manufacturer's instructions. In brief, embryos were placed in vial 1 for $5 \mathrm{~min}$ at room temperature, transferred to vial 2 for $10 \mathrm{~min}$ at room temperature followed by $15 \mathrm{~min}$ in vial 3, also at room temperature, loaded into Cryostraws and stored in liquid nitrogen until time of thawing. Frozen embryos were thawed using the Embryo Thawing Pack (Medicult UK Ltd.), following the manufacturer's instructions. In brief, embryos were removed from liquid nitrogen and left at room temperature for $30 \mathrm{~s}$ before being placed into water at $30^{\circ} \mathrm{C}$. After opening the straw, the contents were placed in vial 1 for $5 \mathrm{~min}$ at room temperature, transferred to vial 2 for $5 \mathrm{~min}$ at room temperature

Table 1 Primer sequences and accession numbers of target genes.

\begin{tabular}{|c|c|c|}
\hline Gene names & Accession numbers & Sequences \\
\hline \multirow[t]{2}{*}{$\beta-A C T I N$} & NM_001101 & F: 5'-AAG CCA CСС САC ТTC ТСТ CТ-3' \\
\hline & & R: 5'-CTA TCA CCT CCC CTG TGT GG-3' \\
\hline \multirow[t]{2}{*}{$B C L 2 L 1$} & NM_001191 & F: 5'-TTG TTA AGC GTG TCT GTA TTT ATG TG-3' \\
\hline & & R: 5'-CAT CAG GCC GTC CAA TCT-3' \\
\hline \multirow[t]{2}{*}{$B C L 2$} & NM_000633 & F: 5'-CAT GGT TAA GGT AAA GTA AGT CTC CA-3' \\
\hline & & R: 5'-ACA ACA CAA ACA AAG TGC CAT T-3' \\
\hline \multirow[t]{2}{*}{$B A X$} & NM_138765 & F: 5'-CCA GCT GCC TTG GAC TGT CTT TTT T-3' \\
\hline & & R: 5'-ACC CCC TCA AGA CCA CTC-3' \\
\hline \multirow[t]{2}{*}{ TP53 } & NM_000546 & F: 5'-AAA AGG AAA TCT CAC CCC ATC-3' \\
\hline & & R: 5'-AGT CTT GGT GGA TCC AGA TCA-3' \\
\hline \multirow[t]{2}{*}{ GAS5 } & NR_002578 & F: 5'-CAT TGG CAC ACA GGC ATT AG-3' \\
\hline & & R: 5'-TAA GCT GGT CCA GGC AAG TT-3' \\
\hline \multirow[t]{2}{*}{ POU5F1 } & NM_203289 & F: 5'-GCT AGG GAA AGA AAA CCT GGA GTT-3' \\
\hline & & R: 5'-TGT TCC CAA TTC CTT CCT TAG TG-3' \\
\hline \multirow[t]{2}{*}{ SOX2 } & NM_003106 & F: 5'-CAC ACT GCC CCT CTC ACA CAT- $3^{\prime}$ \\
\hline & & R: 5'-CAT TTC CCT CGT TTT TCT TTG AA-3' \\
\hline \multirow[t]{2}{*}{ NANOG } & NM_024865 & F: 5'-CGC CCT GCC TAG AAA AGA CA-3' \\
\hline & & R: 5'-GCC AGA GAC GGC TTC TAT CAA-3' \\
\hline \multirow{2}{*}{ ZFP42 } & NM_020695 & F: 5'-CTC CGT GAC CTC TGA GAA CC-3' \\
\hline & & R: 5'-GGC TCT AGC GGG AAG ACA GT-3' \\
\hline \multirow[t]{2}{*}{$C D \times 2$} & NM_001265 & F: 5'-GGT GGC CTG CGT CTT TTT T-3' \\
\hline & & R: 5'-CAT ACC ACA CCC TGT GCA TAC AC-3' \\
\hline \multirow[t]{2}{*}{ EOMES } & NM_005442 & F: 5'-GGC TTT TGG AAC AAG CCA TGT-3' \\
\hline & & R: 5'-GCA GAG GCC TAG CAA GTC TCA-3' \\
\hline \multirow[t]{2}{*}{$D A Z L$} & NM_001351 & F: 5'-ACA AAC TAA ACT TTA CTA GGT ACA TAA GCT TCT C-3' \\
\hline & & R: $5^{\prime}$-AGC CAA GTT TAG CAT TTC AAA GAA A-3' \\
\hline \multirow[t]{2}{*}{ EIF1AX } & NM_001412 & F: 5'-AAA CCA TGA TTG CTG CTT TTC C-3' \\
\hline & & R: 5'-GAG ACA AGG CAA ATG ATT TCT TCA-3' \\
\hline \multirow[t]{2}{*}{ FIGLA } & NM_001004311 & F: 5'-CAC ATA CAT CCT CGG CAA GAC A-3' \\
\hline & & R: 5'-TTC ATT CTT CAA GCC GAA AGC-3' \\
\hline \multirow[t]{2}{*}{ NLRP5 } & NM_153447 & F: 5'-CGG TAG TTG CAT TCT TTT GA-3' \\
\hline & & R: 5'-GGC AGG TTT CCG TAT CTT CA-3' \\
\hline \multirow[t]{2}{*}{ ZAR1 } & NM_175619 & F: 5'-TCA TGA AGT ATT TTG AGA AGG GAG A-3' \\
\hline & & R: 5'-GCG CTG ATG GAG TAG ACG A-3' \\
\hline \multirow[t]{2}{*}{ ZSCAN4 } & NM_152677 & F: 5'-AAA GAA GCC TTT CAC ATG CAG-3' \\
\hline & & R: 5'-TGA GAC CGC AGG TTG GTT-3' \\
\hline \multirow[t]{2}{*}{ TSC2 } & NM_000548 & F: 5'-TCC GTC CCA TAG CAA AGC-3' \\
\hline & & R: 5'-CTC CAC CGA GGA GAT GAG G-3' \\
\hline
\end{tabular}


followed by $10 \mathrm{~min}$ in vial 3, also at room temperature. Embryos were then placed in medium from vial 4, washed in G1 media (Vitrolife, Göteborg, Sweden) and replaced into the incubator for recovery and culture before lysis. Twenty-five thawed 2PN embryos were assessed to be have survived the freeze-thaw process ( $\sim 50 \%$ survival rate), with no obvious damage to the zona pellucida. Five of the thawed $2 \mathrm{PN}$ embryos were then allowed a short recovery period of $3 \mathrm{~h}$ before lysis and qPCR. The remaining thawed embryos were then cultured to the four-cell, eight-cell and blastocyst stage $(n=8,5$ and 7 respectively) before lysis and qPCR was performed.

Nineteen stage and morphologically matched fresh embryos donated to research were collected at the two- to four-cell stage on day 2 of development and further cultured until the required stage was reached (four-cell $n=6$, eight-cell $n=5$ and blastocyst $n=7$ ) before lysis and qPCR was performed. Fresh 2PN embryos were not available to the project as these were always used for patient treatment.

Early cleavage stage embryos were cultured to the eight-cell stage in $50 \mu \mathrm{l}$ G1 media (Vitrolife) overlaid in liquid paraffin (Vitrolife) at $37^{\circ} \mathrm{C}$ in $5 \% \mathrm{CO}_{2}$ in air. Fresh and frozen embryos from the eight-cell stage to the blastocyst stage were cultured in $50 \mu \mathrm{l}$ drops of G2 media (Vitrolife).

\section{Embryo lysis, RT and global amplification (PolyAPCR)}

PolyAPCR was performed to amplify mRNA, as described by Brady \& Iscove (1993). This procedure amplifies all polyadenylated RNA in a given sample. The cDNA collection thus produced preserves the relative abundance of the mRNAs present in the original sample. Oocytes and embryos were lysed and reverse transcribed as described previously (Brady \& Iscove
1993, Bloor et al. 2002, Kimber et al. 2008). PCR amplification of the polyAcDNA product was performed using two linked sets of 25 cycles. The first 25 cycles were denaturation at $94{ }^{\circ} \mathrm{C}$ for $1 \mathrm{~min}$, primer annealing at $42{ }^{\circ} \mathrm{C}$ for $2 \mathrm{~min}$ and extension at $72{ }^{\circ} \mathrm{C}$ for $6 \mathrm{~min}$, and the second 25 cycles were denaturation at $94{ }^{\circ} \mathrm{C}$ for $1 \mathrm{~min}$, primer annealing at $42{ }^{\circ} \mathrm{C}$ for $2 \mathrm{~min}$ and extension at $72{ }^{\circ} \mathrm{C}$ for $1 \mathrm{~min}$. PolyAcDNA was then subjected to a second round of amplification as described previously (Bloor et al. 2002) but with modification to cycling parameters. Briefly, $1 \mu$ l polyAcDNA template was added to a final reaction volume of $50 \mu \mathrm{l}$ containing $10 \mathrm{mmol} / \mathrm{l}$ Tris- $\mathrm{HCl}, \mathrm{pH} 8.3$, $1.5 \mathrm{mmol} / \mathrm{l} \mathrm{MgCl}_{2}, 50 \mathrm{mmol} / \mathrm{l} \mathrm{KCl}, 0.2 \mathrm{mmol} / \mathrm{l} \mathrm{dNTPs}$, $2 \mu \mathrm{mol} / \mathrm{I} \mathrm{NotldT}_{24}$ primer and $0.025 \mathrm{IU} / \mu \mathrm{l}$ Taq polymerase (Roche). Amplification parameters consisted of 25 cycles of denaturation at $95{ }^{\circ} \mathrm{C}$ for $15 \mathrm{~s}$, annealing at $42{ }^{\circ} \mathrm{C}$ for $30 \mathrm{~s}$ and extension at $72{ }^{\circ} \mathrm{C}$ for $1 \mathrm{~min}$. Given the nature of our amplification method (global amplification followed by genespecific PCR), we do not class a gene to be expressed unless it is detected before 37 cycles with real-time PCR. Although low-level signal for some genes could be detected in certain samples, we have not recorded this as 'true expression' if this level falls outside of our inclusion criteria.

\section{Normalisation of polyAcDNA samples for real-time $q P C R$}

Expression of $\beta$-ACTIN served as the inclusion criteria for all samples; those that did not express $\beta$-ACTIN were omitted from the study as per our standard protocols (Bloor et al. 2002, Kimber et al. 2008). Normalisation of the double-stranded polyAcDNA samples was performed using the PicoGreen Assay according to the manufacturer's instructions (Invitrogen).

Table 2 A comparison of the number of individual embryos expressing cell fate genes in frozen-thawed and fresh four-cell, eight-cell and blastocyst samples. Significant differences were detected in the number of embryos expressing OCT3B/4, ZFP42, CDX2 and EOMES at the four-cell stage. At the eight-cell stage, CDX2 was absent from all frozen-thawed eight-cell embryos but was detected in all fresh eight-cell embryos. A significantly higher proportion of frozen-thawed embryos at the blastocyst stage expressed NLRP5 when compared to their fresh counterparts.

\begin{tabular}{|c|c|c|c|c|c|c|}
\hline \multirow[b]{2}{*}{ Genes } & \multicolumn{2}{|c|}{ Four-cell embryos } & \multicolumn{2}{|c|}{ Eight-cell embryos } & \multicolumn{2}{|c|}{ Blastocysts } \\
\hline & Frozen & Fresh & Frozen & Fresh & Frozen & Fresh \\
\hline$\beta$-ACTIN & $8 / 8$ & $6 / 6$ & $5 / 5$ & $5 / 5$ & $7 / 7$ & $8 / 8$ \\
\hline$B C L 2 L 1$ & $7 / 8$ & $6 / 6$ & $2 / 5$ & $5 / 5$ & $7 / 7$ & $8 / 8$ \\
\hline$B C L 2$ & $0 / 8$ & $0 / 6$ & $0 / 5$ & $1 / 5$ & $0 / 7$ & $1 / 8$ \\
\hline$B A X$ & $2 / 8$ & $1 / 6$ & $1 / 5$ & $2 / 5$ & $6 / 7$ & $5 / 8$ \\
\hline TP53 & $3 / 8$ & $1 / 6$ & $2 / 5$ & $0 / 5$ & $5 / 7$ & $4 / 8$ \\
\hline GAS5 & $8 / 8$ & $4 / 6$ & $5 / 5$ & $5 / 5$ & $6 / 7$ & $7 / 8$ \\
\hline POU5F1 & $8 / 8^{*}$ & $2 / 6$ & $5 / 5$ & $4 / 5$ & $7 / 7$ & $6 / 8$ \\
\hline SOX2 & $6 / 8$ & $2 / 6$ & $5 / 5$ & $4 / 5$ & $7 / 7$ & $5 / 8$ \\
\hline NANOG & $4 / 8$ & $1 / 6$ & $5 / 5$ & $1 / 5$ & $7 / 7$ & $7 / 8$ \\
\hline ZFP42 & $8 / 8^{*}$ & $2 / 6$ & $5 / 5$ & $3 / 5$ & $7 / 7$ & $6 / 8$ \\
\hline$C D \times 2$ & $0 / 8^{\ddagger}$ & $6 / 6$ & $0 / 5^{+}$ & $5 / 5$ & $6 / 7$ & $8 / 8$ \\
\hline EOMES & $8 / 8^{*}$ & $2 / 6$ & $5 / 5$ & $2 / 5$ & $4 / 7$ & $4 / 8$ \\
\hline$D A Z L$ & $2 / 8$ & $3 / 6$ & $2 / 5$ & $1 / 5$ & $3 / 7$ & $2 / 8$ \\
\hline EIF1AX & $7 / 8$ & $2 / 6$ & $5 / 5$ & $2 / 5$ & $7 / 7$ & $5 / 8$ \\
\hline FIGLA & $6 / 8$ & $1 / 6$ & $3 / 5$ & $3 / 5$ & $2 / 7$ & $2 / 8$ \\
\hline NLRP5 & $8 / 8$ & $3 / 6$ & $5 / 5$ & $3 / 5$ & $7 / 7^{*}$ & $1 / 8$ \\
\hline ZAR1 & $8 / 8$ & $3 / 6$ & $5 / 5$ & $4 / 5$ & $7 / 7$ & $4 / 8$ \\
\hline ZSCAN4 & $4 / 8$ & $1 / 6$ & $5 / 5$ & $5 / 5$ & $2 / 7$ & $6 / 8$ \\
\hline TSC2 & $3 / 8$ & $2 / 6$ & $3 / 5$ & $2 / 5$ & $7 / 7$ & $5 / 8$ \\
\hline
\end{tabular}

${ }^{*} P<0.05,{ }^{\dagger} P<0.01$ and ${ }^{\ddagger} P<0.001$. 
Table 3 Average number of genes expressed at the four-cell, eight-cell and blastocyst stages in frozen-thawed and fresh embryos. Overall, the frozen embryo panel expressed a higher number of genes on average but the difference was not significant.

\begin{tabular}{llll}
\hline & Four-cell & Eight-cell & Blastocyst \\
\hline Frozen embryos & 12.4 & 13.6 & 14.85 \\
Fresh embryos & 8 & 11.4 & 11.75 \\
\hline
\end{tabular}

The PicoGreen assay is a sensitive assay for the detection of double-stranded DNA in solution and it has been validated as an appropriate method to correct for variability in cDNA between samples for real-time qPCR analysis (Whelan et al. 2003). Our experience shows that the use of housekeeping genes to normalise qPCR data is inappropriate for this type of embryo study as reference genes such as $\beta$-ACTIN demonstrated variability in expression levels. The expression of target genes (Table 1) was assessed by qPCR using Power SYBR Green Master Mix (Applied Biosystems, Paisley, UK) according to the manufacturer's instructions. Each $25 \mu \mathrm{l}$ reaction contained $6.25 \mathrm{ng}$ polyAcDNA template and the cycling was performed in an ABI 7300 real-time PCR system (Applied Biosystems) under the following parameters: $95^{\circ} \mathrm{C}$ for $10 \mathrm{~min}$ followed by 40 cycles at $95^{\circ} \mathrm{C}$ for $30 \mathrm{~s}, 60^{\circ} \mathrm{C}$ for $30 \mathrm{~s}$ and $72{ }^{\circ} \mathrm{C}$ for $35 \mathrm{~s}$. A final extension at $72{ }^{\circ} \mathrm{C}$ for $10 \mathrm{~min}$ preceded melt curve analysis (identification of a single peak) at the end of the sequence. Reactions for each individual sample were performed in triplicate. $\Delta C \mathrm{t}$ was calculated as 40- $C$ t value.

\section{Sequencing analysis}

Amplified PCR products were sequenced by the Sequencing Facility at the University of Manchester. Products were sequenced in the reverse direction using an ABI Prism 377 sequencer (Applied Biosystems). Data were analysed using Chromas Software version 1.45 (Technelysium Pty Ltd., South Brisbane, Queensland, Australia) and the data for each sequence was copied into the National Centre for Biotechnology Information BLAST database (http://www.ncbi. nih.gov/BLAST). A search for matching sequences confirmed the authenticity of the amplified products.

\section{Statistical analysis}

The mean $\Delta C$ t values for each sample triplicate was calculated and imported into GraphPad Prism version 3.0 Software (Hearne Scientific Software, Victoria, Australia) and analysed using the Kruskal-Wallis one-way ANOVA by rank test, a nonparametric method used where the data do not assume a normal distribution. To determine statistical difference between individual groups, the Dunn's multiple comparison test was applied. The Fisher's exact probability test was used to determine any significant differences between the number of individual embryos expressing a particular gene in stagematched frozen and thawed samples (Tables 2 and 3).

\section{Declaration of interest}

The authors declare that there is no conflict of interest that could be perceived as prejudicing the impartiality of the research reported.

\section{Funding}

This study was supported by the Central Manchester National Health Service Foundation Trust, the National Institute for Health Research Manchester Biomedical Research Centre, the United Kingdom Medical Research Council and Cancer Research UK.

\section{Acknowledgements}

The authors wish to acknowledge the staff and patients of the IVF unit, Department of Reproductive Medicine, St Mary's Hospital and Manchester Fertility Services, Manchester, United Kingdom for embryo donation.

\section{References}

Aytoz A, Van den Abbeel E, Bonduelle $M$, Camus $M$, Joris $\mathbf{H}$, Van Steirteghem A \& Devroey P 1999 Obstetric outcome of pregnancies after the transfer of cryopreserved and fresh embryos obtained by conventional in-vitro fertilization and intracytoplasmic sperm injection. Human Reproduction 14 2619-2624. (doi:10.1093/ humrep/14.10.2619)

Belva F, Henriet S, Van den Abbeel E, Camus M, Devroey P, Van der Elst J, Liebaers I, Haentjens P \& Bonduelle M 2008 Neonatal outcome of 937 children born after transfer of cryopreserved embryos obtained by ICSI and IVF and comparison with outcome data of fresh ICSI and IVF cycles. Human Reproduction 23 2227-2238. (doi:10.1093/humrep/ den254)

Bloor DJ, Metcalfe AD, Rutherford A, Brison DR \& Kimber SJ 2002 Expression of cell adhesion molecules during human preimplantation embryo development. Molecular Human Reproduction 8 237-245. (doi:10.1093/molehr/8.3.237)

Boumela I, Assou S, Aouacheria A, Haouzi D, Dechaud H, De Vos J, Handyside A \& Hamamah S 2011 Involvement of BCL2 family members in the regulation of human oocyte and early embryo survival and death: gene expression and beyond. Reproduction 141 549-561. (doi:10.1530/ REP-10-0504)

Brady G \& Iscove NN 1993 Construction of cDNA libraries from single cells. Methods in Enzymology 225 611-623.

Braude P, Bolton V \& Moore S 1988 Human gene expression first occurs between the four- and eight-cell stages of preimplantation development. Nature 332 459-461. (doi:10.1038/332459a0)

Brison DR 2000 Apoptosis in mammalian preimplantation embryos: regulation by survival factors. Human Fertility 3 36-47. (doi:10.1080/ 1464727002000198671)

Brison DR \& Schultz RM 1997 Apoptosis during mouse blastocyst formation: evidence for a role for survival factors including transforming growth factor alpha. Biology of Reproduction 56 1088-1096. (doi:10.1095/biolreprod56.5.1088)

Cauffman G, Van de Velde H, Liebaers I \& Van Steirteghem A 2005 DAZL expression in human oocytes, preimplantation embryos and embryonic stem cells. Molecular Human Reproduction 11 405-411. (doi:10.1093/ molehr/gah167)

Chambers I, Colby D, Robertson M, Nichols J, Lee S, Tweedie S \& Smith A 2003 Functional expression cloning of Nanog, a pluripotency sustaining factor in embryonic stem cells. Cell 113 643-655. (doi:10.1016/S00928674(03)00392-1) 
Chandrakanthan V, Chami O, Stojanov T \& O'Neill C 2007 Variable expressivity of the tumour suppressor protein TRP53 in cryopreserved human blastocysts. Reproductive Biology and Endocrinology 539. (doi:10.1186/1477-7827-5-39)

Copp AJ 1995 Death before birth: clues from gene knockouts and mutations. Trends in Genetics 11 87-93. (doi:10.1016/S0168-9525 (00)89008-3)

Cui XS \& Kim NH 2007 Maternally derived transcripts: identification and characterisation during oocyte maturation and early cleavage. Reproduction, Fertility, and Development 19 25-34. (doi:10.1071/RD06128)

Fleming TP 1987 A quantitative analysis of cell allocation to trophectoderm and inner cell mass in the mouse blastocyst. Developmental Biology 119 520-531. (doi:10.1016/0012-1606(87)90055-8)

Gardner DK \& Schoolcraft WB 1999 Culture and transfer of human blastocysts. Current Opinion in Obstetrics \& Gynecology 11 307-311. (doi:10.1097/00001703-199906000-00013)

Gardner DK \& Lane M 2005 Ex vivo early embryo development and effects on gene expression and imprinting. Reproduction, Fertility, and Development 17 361-370. (doi:10.1071/RD04103)

Gasca S, Pellestor F, Assou S, Loup V, Anahory T, Dechaud H, De Vos J \& Hamamah S 2007 Identifying new human oocyte marker genes: a microarray approach. Reproductive Biomedicine Online 14 175-183. (doi:10.1016/S1472-6483(10)60785-7)

Goto K, Muguruma K, Kuramochi T, Shimozawa N, Hioki K, Itoh T \& Ebukuro M 2002 Effects of cryopreservation of mouse embryos and in vitro fertilization on genotypic frequencies in colonies. Molecular Reproduction and Development 62 307-311. (doi:10.1002/ mrd.10119)

Guillemin Y, Lalle P, Gillet G, Guerin JF, Hamamah S \& Aouacheria A 2009 Oocytes and early embryos selectively express the survival factor BCL2L10. Journal of Molecular Medicine 87 923-940. (doi:10.1007/ s00109-009-0495-7)

Guo G, Huss M, Tong GQ, Wang C, Li Sun L, Clarke ND \& Robson P 2010 Resolution of cell fate decisions revealed by single-cell gene expression analysis from zygote to blastocyst. Developmental Cell 18 675-685. (doi:10.1016/j.devcel.2010.02.012)

Hamatani T, Ko M, Yamada M, Kuji N, Mizusawa Y, Shoji M, Hada T, Asada H, Maruyama T \& Yoshimura Y 2006 Global gene expression profiling of preimplantation embryos. Human Cell 19 98-117. (doi:10.1111/j.1749-0774.2006.00018.x)

Hamel M, Dufort I, Robert C, Gravel C, Leveille MC, Leader A \& Sirard MA 2008 Identification of differentially expressed markers in human follicular cells associated with competent oocytes. Human Reproduction 23 1118-1127. (doi:10.1093/humrep/den048)

Hansis C, Grifo JA \& Krey LC 2000 Oct-4 expression in inner cell mass and trophectoderm of human blastocysts. Molecular Human Reproduction 6 999-1004. (doi:10.1093/molehr/6.11.999)

Hardy K 1999 Apoptosis in the human embryo. Reviews of Reproduction 4 125-134. (doi:10.1530/ror.0.0040125)

Jurisicova A, Latham KE, Casper RF \& Varmuza SL 1998 Expression and regulation of genes associated with cell death during murine preimplantation embryo development. Molecular Reproduction and Development 51 243-253. (doi:10.1002/(SICl)1098-2795(199811)51:3 $<243:: A I D-M R D 3>3.0 . C O ; 2-P)$

Kimber SJ 1990 Glycoconjugates and cell surface interactions in pre- and peri-implantation mammalian embryonic development. International Review of Cytology 120 53-167.

Kimber SJ, Sneddon SF, Bloor DJ, El-Bareg AM, Hawkhead JA, Metcalfe AD, Houghton FD, Leese HJ, Rutherford A, Lieberman BA et al. 2008 Expression of genes involved in early cell fate decisions in human embryos and their regulation by growth factors. Reproduction 135 635-647. (doi:10.1530/REP-07-0359)

Li L, Zheng P \& Dean J 2010 Maternal control of early mouse development. Development 137 859-870. (doi:10.1242/dev.039487)

Magnani L, Johnson CM \& Cabot RA 2008 Expression of eukaryotic elongation initiation factor $1 \mathrm{~A}$ differentially marks zygotic genome activation in biparental and parthenogenetic porcine embryos and correlates with in vitro developmental potential. Reproduction, Fertility, and Development 20 818-825. (doi:10.1071/RD08072)

Meier P, Finch A \& Evan G 2000 Apoptosis in development. Nature 407 796-801. (doi:10.1038/35037734)
Metcalfe AD, Hunter HR, Bloor DJ, Lieberman BA, Picton HM, Leese HJ, Kimber SJ \& Brison DR 2004 Expression of 11 members of the BCL-2 family of apoptosis regulatory molecules during human preimplantation embryo development and fragmentation. Molecular Reproduction and Development 68 35-50. (doi:10.1002/mrd.20055)

Palmieri SL, Peter W, Hess H \& Scholer HR 1994 Oct-4 transcription factor is differentially expressed in the mouse embryo during establishment of the first two extraembryonic cell lineages involved in implantation. Developmental Biology 166 259-267. (doi:10.1006/dbio. 1994.1312)

Patrizio P, Fragouli E, Bianchi V, Borini A \& Wells D 2007 Molecular methods for selection of the ideal oocyte. Reproductive Biomedicine Online 15 346-353. (doi:10.1016/S1472-6483(10)60349-5)

Perumalsamy A, Fernandes R, Lai I, Detmar J, Varmuza S, Casper RF \& Jurisicova A 2010 Developmental consequences of alternative Bcl-x splicing during preimplantation embryo development. FEBS Journal 277 1219-1233. (doi:10.1111/j.1742-4658.2010.07554.x)

Pesce M \& Scholer HR 2001 Oct-4: gatekeeper in the beginnings of mammalian development. Stem Cells 19 271-278. (doi:10.1634/ stemcells.19-4-271)

Ralston A \& Rossant J 2005 Genetic regulation of stem cell origins in the mouse embryo. Clinical Genetics 68 106-112. (doi:10.1111/j.13990004.2005.00478.x)

Ralston A \& Rossant J 2008 Cdx2 acts downstream of cell polarization to cell-autonomously promote trophectoderm fate in the early mouse embryo. Developmental Biology 313 614-629. (doi:10.1016/j.ydbio. 2007.10.054)

Roberts S, McGowan L, Hirst W, Brison D, Vail A \& Lieberman B 2010 Towards single embryo transfer? Modelling clinical outcomes of potential treatment choices using multiple data sources: predictive models and patient perspectives Health Technology Assessment 14 1-237. (doi:10.3310/hta14380)

Sena P, Riccio M, Marzona L, Nicoli A, Marsella T, Marmiroli S, Bertacchini J, Fano RA, La Sala GB \& De Pol A 2009 Human MATER localization in specific cell domains of oocytes and follicular cells. Reproductive Biomedicine Online 18 226-234. (doi:10.1016/S14726483(10)60260-X)

Sneddon SF, DeSousa PA, Arnesen RE, Lieberman BA, Kimber SJ \& Brison DR 2011 Gene expression analysis of a new source of human oocytes and embryos for research and human embryonic stem cell derivation. Fertility and Sterility 95 1410-1415. (doi:10.1016/j.fertnstert. 2010.08.050)

Steer CV, Mills CL, Tan SL, Campbell S \& Edwards RG 1992 The cumulative embryo score: a predictive embryo scoring technique to select the optimal number of embryos to transfer in an in-vitro fertilization and embryo transfer programme. Human Reproduction 7 117-119.

Strumpf D, Mao CA, Yamanaka Y, Ralston A, Chawengsaksophak K, Beck F \& Rossant J 2005 Cdx2 is required for correct cell fate specification and differentiation of trophectoderm in the mouse blastocyst. Development 132 2093-2102. (doi:10.1242/dev.01801)

Tachataki M, Winston RM \& Taylor DM 2003 Quantitative RT-PCR reveals tuberous sclerosis gene, TSC2, mRNA degradation following cryopreservation in the human preimplantation embryo. Molecular Human Reproduction 9 593-601. (doi:10.1093/molehr/gag073)

Telford NA, Watson AJ \& Schultz GA 1990 Transition from maternal to embryonic control in early mammalian development: a comparison of several species. Molecular Reproduction and Development 26 90-100. (doi:10.1002/mrd.1080260113)

Trounson A \& Mohr L 1983 Human pregnancy following cryopreservation, thawing and transfer of an eight-cell embryo. Nature 305 707-709. (doi:10.1038/305707a0)

Vassena R, Boue S, Gonzalez-Roca E, Aran B, Auer H, Veiga A \& Izpisua Belmonte JC 2011 Waves of early transcriptional activation and pluripotency program initiation during human preimplantation development. Development 138 3699-3709. (doi:10.1242/dev. 064741)

Vergouw CG, Kostelijk EH, Doejaaren E, Hompes PGA, Lambalk CB \& Schats R 2012 The influence of the type of embryo culture medium on neonatal birthweight after single embryo transfer in IVF. Human Reproduction 27 2619-2926. (doi:10.1093/humrep/des252) 
Watson AJ, Westhusin ME, De Sousa PA, Betts DH \& Barcroft LC 1999 Gene expression regulating blastocyst formation. Theriogenology $\mathbf{5 1}$ 117-133. (doi:10.1016/S0093-691X(98)00236-2)

Wells D, Bermudez MG, Steuerwald N, Malter HE, Thornhill AR \& Cohen J 2005 Association of abnormal morphology and altered gene expression in human preimplantation embryos. Fertility and Sterility 84 343-355. (doi:10.1016/j.fertnstert.2005.01.143)

Wennerholm UB, Söderström-Anttila V, Bergh C, Aittomäki K, Hazekamp J, Nygren KG, Selbing A \& Loft A 2009 Children born after cryopreservation of embryos or oocytes: a systematic review of outcome data. Human Reproduction 24 2158-2172. (doi:10.1093/humrep/ dep125)

Whelan JA, Russell NB \& Whelan MA 2003 A method for the absolute quantification of CDNA using real-time PCR. Journal of Immunological Methods 278 261-269. (doi:10.1016/S0022-1759(03)00223-0)
Wood MJ, Sjoblom P, Lindenberg S \& Kimber SJ 1992 Effect of slow and ultra-rapid freezing on cell surface antigens of 8-cell mouse embryos. Journal of Experimental Zoology 262 330-339. (doi:10.1002/jez. 1402620313)

Zhang P, Zucchelli M, Bruce S, Hambiliki F, Stavreus-Evers A, Levkov L, Skottman H, Kerkela E, Kere J \& Hovatta O 2009 Transcriptome profiling of human pre-implantation development. PLOS ONE 4 e7844. (doi:10.1371/journal.pone.0007844)

Received 8 February 2012

First decision 19 March 2012

Revised manuscript received 18 September 2012

Accepted 20 September 2012 